\title{
Qual é o teu trabalho, mulher? Mulheres empreendedoras no contexto da Economia Popular Solidária
}

Tânia Cristina da Silva Cruz

Curso: Doutorado em Sociologia

Data da defesa: 26 de julho de 2006

Orientadora: $\operatorname{Prof}^{\mathrm{a}} \operatorname{Dr}^{\mathrm{a}}$ Berlindes Astrid Küchemann

\section{Resumo}

Motivada pelas metamorfoses do mundo do trabalho e de sua crise e pela participação das mulheres nesse contexto, a presente tese teve por objetivo refletir sobre o papel social das mulheres empreendedoras solidárias. Nosso foco principal foi o estudo da condição contemporânea das mulheres-trabalhadoras, de modo a compreender a seguinte questão central: Qual o papel das mulheres no processo de geração de alternativas à crise atual do trabalho e como, ao mesmo tempo, tais iniciativas se constituem campos para a geração de vínculos sociais e econômicos?

A partir do estudo do trabalho produtivo e reprodutivo, organizado e mantido por mulheres que vinham de uma trajetória de pobreza e/ou exclusão social, analisamos, empiricamente, a produção de laços sociais contemporâneos, em um contexto de economia popular solidária. O grupo de artesãs Apoena (Vila Estrutural, no Distrito Federal) e a Cooperativa 100 Dimensão (Riacho Fundo II, no Distrito Federal) foram os sujeitos da pesquisa.

O estudo do papel social da mulher no mundo do trabalho passa pelo reconhecimento de que a sua entrada e permanência nele implica uma articulação entre trabalho extradoméstico e trabalho 
doméstico (cuidado com a casa, a família, os filhos, etc.). Assim, as mulheres-trabalhadoras colocadas no centro desta tese são aquelas cuja rotina está estruturada em variadas ações: sobrevivência familiar versus reconhecimento e auto-estima; socialização dos filhos versus inserção ocupacional; dupla jornada de trabalho versus cuidados pessoais, etc. De um modo geral, demonstramos que, entre a casa e a rua, é cada vez maior o número de mulheres que estão buscando reescrever suas trajetórias de socialização de forma a não sucumbirem à exclusão e à invisibilidade social.

Em consonância com o pressuposto de que o trabalho não é apenas gerador de mercadorias, mas, sobretudo, de sociabilidades e identidades positivamente reconhecidas pelos agrupamentos sociais, explicitamos a existência de um tipo contemporâneo de trabalhadoras: as mulheres-empreendedoras solidárias.

Por fim, destacamos a existência de uma economia popular solidária, que favorece o reconhecimento do trabalho das mulheres, especialmente daquelas que vivem em situação de vulnerabilidade, mas empreendem sua força de trabalho na produção e na reprodução social.

Palavras-chave: mulheres-empreendedoras-solidárias, economia popular solidária, crise do trabalho, gênero, papéis sociais das mulheres, socialização, reconhecimento, geração de vínculos, Apoena, 100 Dimensão. 